\title{
The Two-Tier Board Structure and Co-determination: Should South Africa follow the Germany Example?
}

\author{
Linda Muswaka \\ Faculty of Law, North West University, South Africa \\ Email: leemuswaka@gmail.com
}

Doi:10.5901/mjss.2014.v5n9p142

\begin{abstract}
The German corporate governance system differs significantly from the South African system. Unlike the shareholder-oriented corporate governance system that exists in the South Africa, German corporate governance is stakeholder-oriented. Stakeholders, particularly employees, have an important role in German corporate governance. They participate in decisions that affect them directly through workers councils, as well as those that affect the corporation through union representation on the supervisory board. The German corporate governance system is characterized by the two-tier board, with co-determination between employees and shareholders on the supervisory board. This paper examines the German stakeholder-oriented corporate governance. The main concern is whether there are lessons to be drawn from the German model of corporate governance that may influence corporate law reform in South Africa. The paper concludes that for the effective protection of stakeholders' interests, the German two-tier board structure and co-determination provisions should be adopted in South Africa with some variation.
\end{abstract}

Keywords: Corporate Governance, Board Structure, Co-determination, Shareholders, Stakeholders, Directors

\section{Introduction}

The German corporate governance system differs significantly from the South African system. Unlike the shareholderoriented corporate governance system ${ }^{1}$ that exists in the South Africa, German corporate governance is stakeholderoriented. Stakeholders, particularly employees, have an important role in German corporate governance. They participate in decisions that affect them directly through workers councils, as well as those that affect the corporation through union representation on the supervisory board. The German corporate governance system is characterized by the two-tier (management and supervisory) board, with co-determination between employees and shareholders on the supervisory board. ${ }^{2}$ This paper examines the German stakeholder-oriented corporate governance. The aim is extract lessons for South Africa that may influence corporate law reform.

\section{Germany}

According to Mintz, German corporate governance is shaped by a legal tradition that dates back to the 1920s and regards companies as entities which act not only in the interests of their shareholders, but also serve other stakeholder interests. ${ }^{3}$ German companies place their employees in particular, at par with the shareholders. The stakeholder corporate governance approach in Germany is characterized by its two-tier board structure and its system of codetermination. ${ }^{4}$

\footnotetext{
1 The shareholder-oriented corporate governance system is said to be operative in Anglo-American jurisdictions although there are many who feel that some of these jurisdictions are moving towards more of a stakeholder approach to corporate governance. This is due to a number of factors, one of which is the advent of the concept of the enlightened shareholder value approach in the United Kingdom, which has been adopted in South Africa.

${ }^{2}$ This system is concerned with the long-term success of the company, and was developed for reasons of social governance, protection of public interest as extending beyond shareholders and to reduce employee alienation.

${ }^{3}$ Mintz M, "Imrpoving Corporate Governance Systems: A Stakeholder Theory Approach" available at http://aaahq.org/AM2004/cpe /Ethics/Forum_08.pdf, accessed on 18 August 2012.

${ }^{4}$ The modern concept of co-determination goes back to 1919, in particular, the Weimar Constitution 1919 Article 165 which stated, "Workers and staff are appointed to participate with equal rights together with the company in the regulation of wages and working conditions, as well as in the complete economic development of the producing powers." This was the impetus for laws on co-
} 


\subsection{The Two-Tier Board Structure}

According to the German Stock Corporations Act, ${ }^{5}$ a mandatory two-tiered board structure must be established in certain corporations. The German Stock Corporations Act, makes it mandatory for all German stock corporations, ${ }^{6}$ all other business entities with more than five hundred employees and all firms in the iron, steel and mining industries (regardless of their size) to have two boards, the management board ${ }^{7}$ and the supervisory board. ${ }^{8}$ The management board runs the day-to-day operation of the company. It is responsible for independently managing the enterprise in the interest of the enterprise, thus taking into account the interests of the shareholders, its employees and other stakeholders, with the objective of sustainable creation of value. ${ }^{9}$ The supervisory board appoints, supervises and advises the members of the management board and is directly involved in decisions of fundamental importance to the enterprise. ${ }^{10}$ Simultaneous membership of the management board and the supervisory board is not permitted in order to protect the independence of both the management board and the supervisory board.

German legislation strictly separates the functions of the supervisory board and the management board to allow for the creation of optimum effectiveness. In this way, the supervisory board closely scrutinizes the performance of the management board. Thus, the interests of the employees will not be neglected. Germans appear to believe that companies have a human and personal component to them and will produce a general benefit for the company as a whole. ${ }^{11}$ The underlying ideology is that employee participation in the decision-making will promote trust, co-operation and harmony. ${ }^{12}$ Thus, the German two-tier board system encourages employees to participate in the decision-making process. By so doing, it produces a compromise in management between shareholders and employees, and balances the pursuit of short-term profit with social-justice considerations and long-term strategic planning. ${ }^{13}$

\subsection{Co-determination}

Germany has a consensual approach to corporate decision making and encourages labour participation by treating employees as key stakeholders. By participating directly in corporate decision making, employees have some degree of influence and control within the corporation. The word 'co-determination,' or 'Mitbestimmung' in German, refers to a concept for employee consultation and participation in company decisions. The ideology of co-determination is that labour and capital have equal importance and therefore should have an equal voice in running the company. In other words, employees are as much a part of the company as are shareholders. The objectives of co-determination are inter alia to ensure equality between providers of capital and providers of labour, to promote democracy in the economy and to promote social development. ${ }^{14} \mathrm{Co}$-determination also aims to promote adequate control of economic power. Where economic power congregates, control is an important instrument in avoiding its misuse. Whether participating in company decisions or contributing on company matters, the principle is the same in every case: co-determination means coresponsibility. In works councils and supervisory boards the employees, just like the employer, need to keep an eye on the long term development of the company. This is why all of the laws on co-determination are directed towards enabling fruitful co-operation between both sides and creating a productive balance of interests.

The Co-determination Act of 1976 provides for the proportion of employee and shareholder representatives on the supervisory board. In terms of this Act, half of the seats on the Supervisory Board of all companies with more than two thousand employees and all companies in the iron, steel and mining industries (regardless of their size) must be filled by

determination. The Nazi Regime in 1934 passed the "Act to Regulate National Work" (Gesetz zur Ordnung der Nationalen Arbeit). This law repealed the Works Council Act of 1920. As a result, provision for works councils and worker participation on the supervisory board came to an end. The current system of employee participation in corporate governance arose out of the aftermath of World War II.

${ }^{5}$ German Stock Corporations Act 1965 (Aktiengesetz - AktG)

6 In German, these are known as Actiengesellschaft(AG).

7 In German it is called the 'Vorstand.'

8 In German it is called the 'Aufsichtsrat.'

9 The German Corporate Governance Code 20136.

10 The German Corporate Governance Code 20132.

11 Wei Y, "Comparative Corporate Governance A Chinese Perspective, Global Trade and FinanceSeries," 2003 (3) Kluwer Law International 2.

12 Lutter M“The German System of Worker Participation in Practice" 1982 Journal of Business Law 154.

${ }^{13}$ Clarke and Bostock, "Governance in Germany: The foundations of Corporate Structure?" In: Corporate Governance by Keasey (1997) 233241.

${ }^{14}$ Through a better consideration of employees' interests when making establishment and company decisions, co-determination contributes to the improvement of working people's living and working conditions. 
representatives of employees or the trade union. ${ }^{15}$ The Chairperson of the supervisory board, whose vote counts double in the case of a tie, is elected by shareholders, however. The proportion of employee representatives falls to one third in companies with less than two thousand but more than five hundred employees. ${ }^{16}$

The main effect of the Co-determination Act is that requiring fair employee representation on the supervisory board forces direct negotiation and resolution of employee-based concerns. Traditionally, these concerns centered on conditions of employment and salary increases, but they could also reach broader issues, such as community support and environmental concerns. It is however questionable whether employees do have a stronger inclination to consider the community or the environment than shareholders or management generally. While this may be difficult to assert, one thing that is certain is that where workers live in a community, they would most likely be concerned with corporate policies that adversely affect the community.

\subsection{The German Corporate Governance Code 2013}

The German Corporate Governance Code, as amended on 13 May 2013, aims to make the German corporate governance system transparent. ${ }^{17}$ Its purpose is to promote the trust of international and national investors, customers, employees and the general public in the management and supervision of listed German stock corporations. ${ }^{18}$ The recommendations of the Code are identified by the use of the word "shall." Companies can deviate from them, but are then obliged to disclose this annually and to justify the deviations (comply or explain). ${ }^{19}$ The Code therefore contributes to more flexibility and more self-regulation in the German corporate constitution. Furthermore, the Code contains suggestions which can be deviated from without disclosure; for this the Code uses the term "should."20 Primarily, the Code addresses listed companies though it is recommended that all companies respect the Code.

The Code promotes co-operation between the management board and the supervisory board. It clarifies the obligation of the management board and the supervisory board to ensure the continued existence of the enterprise and its sustainable creation of value in conformity with the principles of the social market economy. ${ }^{21}$ The Code highlights the fact that good corporate governance requires an open discussion between the management board and supervisory board as well as among the members within the management board and the supervisory board. ${ }^{22}$

\section{South Africa - The Unitary Board Structure}

South African company law provides for a unitary board structure. ${ }^{23}$ This board structure entrusts both management and control in the hands of the board of directors, who are ultimately vested with universal powers. Section 66(1) of the Companies Act provides that the business and affairs of a company must be managed by or under the direction of its board, which has the authority to exercise all the powers and perform any functions of the company, except to the extent that the Act or the company's Memorandum of Incorporation provides otherwise. The board is therefore, the focal point of the corporate governance system. ${ }^{24}$ It gives strategic direction to the company. ${ }^{25}$ While the board may reserve specific

\footnotetext{
${ }^{15}$ Clarke and Bostock, "Governance in Germany: The foundations of Corporate Structure?" In: Corporate Governance by Keasey (1997) 233238.

$16 \mathrm{lbid}$.

${ }^{17}$ The German Corporate Governance Code 20131 available at http://www.corporate-governance-code.de/eng/download/kodex_2013 /D_CorGov_final_May_2013.pdf, accessed on 27 June 2013.

$18 \mathrm{lbid}$.

19 The German Corporate Governance Code 20132.

20 lbid.

21 The German Corporate Governance Code 20132.

22 The German Corporate Governance Code 20134.

${ }^{23}$ Unitary board structure is one in terms of which the company has only one board of directors consisting of both executive and nonexecutive directors.

${ }^{24}$ King III Principle 2.129 . In R v Kritzinger 1971 (2) SA 57 (A) the point was made that a company is an artificial person that cannot read a written representation or hear a spoken representation. It reads or hears a representation through the eyes or ears of, inter alia, its directors acting in the course of their duty, and "board" is the collective term used to designate the directors when they act together in the course of their duty to the company.

25 King III paragraph 529.
} 
powers to it and delegate to other levels of management other matters with the necessary written authority, ${ }^{26}$ any such delegations by the board must have due regard for the director's statutory and common law duties to the company, while taking into account strategic and operational effectiveness and efficiencies. Although the board may delegate authority, there is an important distinction between a delegation and an abdication of powers. In other words, delegating authority to management or board committees does not in any way mitigate or dissipate the discharge by the board and its directors of their duties and responsibilities. ${ }^{27}$ Board committees are an aid to assist the board and its members in discharging their duties and responsibilities, and boards cannot shield behind these committees.

With regard to the board of directors, critics may argue that one area that needs special attention is the method by which directors are appointed. It is important to note that in a formal sense, a company's shareholders elect the directors and have to vote separately on each candidate ${ }^{28}$ but as a practical matter the shareholders usually simply ratify a list of recommended candidates. Traditionally, the chairman ${ }^{29}$ of the board decided who would be nominated and he chose people whom he knew. It was also common for the chairman to be the company's top executive, often referred to as the Chief Executive Officer. ${ }^{30}$ Correspondingly, in many instances a company's leading manager in effect selected the individuals who were charged with the task of monitoring managerial performance. Since individual directors tend to be loyal to those who arrange for their appointment, whenever a single individual is a company's chairman of the board and CEO, doubts about bias understandably can arise. ${ }^{31}$

The difficulty posed by managers appointing their own monitors has diminished recently in South Africa. This is because it has become standard practice in companies to split the roles of the CEO and chairman. ${ }^{32}$ The other reason is that it is becoming common for a nominating committee composed of outside directors to carry out the task of finding new board members. Be that as it may, one may argue that objectivity is still far from assured. This is so because in companies with nominating committees, the CEO can often continue to play a significant 'behind the scenes' role in selecting nominees. Also, when there is a CEO-chairman split, relations between a company's chairman and the chief executive officer are usually close and collegial in nature. Part of the reason is that it is reasonably common for the chairman to work on a full time basis for the company ${ }^{33}$ or to be the company's former $\mathrm{CEO}^{34}$ and a supporter of his appointed successor. ${ }^{35}$ In addition, friction between a chairman and the CEO can paralyze the management team and rob a company of its sense of direction. ${ }^{36}$ Assuming a strong working relationship does exist, the chairman will probably consult with the CEO about the nomination process and he will in any case seek to nominate individuals to the board who 'fit in' with the company. These will be people who will identify with the company's goals and methods of operation and are compatible with the management team. Thus, despite some changes which affect the manner in which directors are selected, doubts about bias must remain.

${ }^{26}$ King III paragraph 49-50 36. See also Section 72 of the Companies Act which provides that, except to the extent that the Memorandum of Incorporation provides otherwise, the board of directors may appoint any number of board committees, and it may delegate any of the authority of the boards to a committee.

${ }^{27}$ See section 72(3) of the Companies Act which states that the board of directors or the particular director will remain liable for the proper performance of a director's duty despite the delegation of the duty to a committee.

${ }^{28}$ See section 70 of the Companies Act.

${ }^{29}$ The term 'chairman' also used in King III has been used as an indication of the office of the individual who heads a company's board of directors rather than 'chairperson' which has, in an attempt to be gender neutral become fairly common.

${ }^{30}$ Hereafter, CEO.

${ }^{31}$ Demb A and Neubauer FF,"The Corporate Board: Confronting the Paradoxes" 1992 (25)3Long Range Planning 12, available at http://www.sciencedirect.com/science/article/pii/0024630192903648, accessed on 10 April 2011; Cox JD and Munsinger HL "Bias in the Boardroom: Psychological Foundations and Legal Implications of Corporate Cohesion" (1985) 48 Law and Contemp. Problems 83 9199.

32 The King Committee's recommendation that the functions of the chief executive officer and the chairman of a company should be separated - see King III Principle 2. 1634 has been enforced by the market in respect of all companies listed on the JSE. It has also been recommended that the chairman should preferably be an independent non-executive director - see King III Principle 2. 1634.

${ }^{33}$ King III however recommends that the board should elect a chairman of the board who is an independent non-executive director - see King III Principle 2.16 34.King III further recommends that if the board appoints a chairman who is a non-executive director but is not independent or is an executive director, this should be disclosed in the integrated report, together with the reasons and justifications for the appointment - see King III paragraph 3934.

${ }^{34}$ According to King III, the retired CEO should not become the chairman of the board until three years have passed since the end of the CEO's tenure as an executive director - see King III paragraph 4235.

${ }_{35}$ Clutterbuck $D$ and Waine $P$ The Independent Board Director (1993) 41.

36 On the importance of a good working relationship, see Walters $P$ "The Role of the Chairman and Chief Executive: An Industrialist's View" in Sheikh S and Rees W (eds) Corporate Governance and Corporate Control (1995) 213-216. 


\section{Commentary}

The unitary board system can be seen as a mechanism geared to further the interests of shareholders as stakeholders are given very little or no recognition nor representation to ensure some form of protection and furtherance of their interests. It for instance, fails to provide key stakeholders with rights enabling them to engage in the decision-making processes of the company at an adequate level. 'Key stakeholders' refers to stakeholders collectively, with legitimate interests in the business, stakeholders that merit and receive consideration in business decisions. Each company will have a different set of key stakeholders, depending on its core business. A socially responsible business should attend to the legitimate interests of all of its key stakeholders and also act in their interest. Key stakeholders, like shareholders, contribute to the success of the company. Shareholders contribute financial capital and the contribution of key stakeholders comes in different forms, depending on the nature of the stakeholder group. For instance, employees contribute "skill, time and effort"(or human capital). ${ }^{37}$

Given that key stakeholders are investors in a company, and if we are to accept the premise of the stakeholder approach, ${ }^{38}$ then there is perhaps a strong argument to be advanced for the equal treatment of key stakeholders and shareholders. In this regard, it is submitted that the German based two-tier board structure and its co-determination provisions are most effective in ensuring the protection of stakeholders' interests. It is however, noted that it is only to the extent that stakeholder questions are questions about employee interests, that the German system would seem to provide an example of progressive stakeholder legislation. In light of the fact that large companies have stakeholders other than their employees and shareholders, it is fair to inquire whether the German model is responsive to the interests of those other stakeholders. For instance, if a German mining company is considering commencing mining operations in a particular community, to what extent would those community interests get a fair hearing before the corporate decision makers? It is submitted that by excluding other relevant stakeholders from representation on the supervisory board, the German system protects employees to the exclusion of all other stakeholders.

\section{Recommendations and Conclusion}

Key stakeholders in a company are interested in the outcome of decisions that affect them directly and indirectly. They have an important role in corporate governance. Key stakeholders need to participate in corporate governance in order to ensure the success of the company ${ }^{39}$ and to protect their stake in the company. This is achieved through their power to influence decision making over certain aspects of the company's activities. The strongest form of stakeholder participation, under a stakeholder oriented corporate governance system, is board representation, whereby key stakeholder representatives sit on the company's board of directors. In this regard, two recommendations are made. First, it is recommended that the German based two-tier board structure be adopted in South Africa. In this regard, the Companies Act should be amended to include the following provision:

66A Two-Tier Board Structure

(1) This provision applies to -

a) all companies listed on the Johannesburg Stock Exchange;

b) all companies with more than five hundred employees; and

c) all companies in the mining sector regardless of their size.

(2) A company to which this provision applies must have two boards, the management board mandated with the running of the day-to-day operations of the company and the supervisory board whose core function will be to appoint, supervise and advise the members of the management board and will also be directly involved in decisions of fundamental importance to the company.

(3) Simultaneous membership of the management board and the supervisory board is prohibited.

Secondly, it is recommended that the German based co-determination laws be adopted with some variation in the Companies Act. The Companies Act should provide for the proportion of not only employee and shareholder representatives on the supervisory board as in Germany but of shareholders and all key stakeholders' representatives of a company. Furthermore, unlike in Germany where the chairperson of the supervisory board, whose vote counts double

${ }^{37}$ Greenfield K, "The Place of Workers in Corporate Law" (1998) 39 B.C.L. Rev. 283.

38 The stakeholder approach is based on the premise that each group of stakeholders merits consideration for its own sake and not merely because of its ability to further the interests of some groups, such as shareholders.

39 The success of the company effectively protects stakeholders' interests and it should be expected that key stakeholders have a right to some influence over decision making to ensure that their interests are adequately protected. 
in the case of a tie, is elected by shareholders, it is recommended that in the South African context, the chairperson be appointed by members of the supervisory board. In this regard, and in line with the previous recommendation, the Companies Act should be amended to include the following provision:

66B Composition of the Supervisory Board

(1) A company to which the two-tier board structure in terms of section $66 \mathrm{~A}$ applies, shall have half the seats on the supervisory board being held by shareholders and the other half being held by representatives of all key stakeholders of the company in equal proportion.

(2) The Chairperson of the supervisory board, whose vote counts double in the case of a tie, is elected members of the supervisory board.

The main effect of the above recommended provisions would be that the Companies Act, by requiring certain companies to have a two-tier board structure and a fair key stakeholder representation on the supervisory board, forces direct negotiation and resolution of stakeholders' concerns. It would encourage key stakeholders' to participate in the decision-making process of the company. By permitting key stakeholders to participate in corporate decision making, they are able to individually participate in ensuring the success of the company and the protection of their interests. It is therefore, important for key stakeholders to have a role in corporate governance and the ability to participate in the decision making of the company.

\section{References}

Benade, M. L., J. J. Henning, J. J. Du Plessis, P. A. Delport, L. De Koker \& J. Pretorius (2008). Entrepreneurial Law. Special ed. Durban: LexisNexis.

Cassim FHI, Cassim MF, Cassim R, Jooste R, Shev J and Yeats J Contemporary Company Law 2011703.

Davies D, Cassim F, Geach W, Mongalo T, Butler D, Loubser A, Coetzee L and Burdett D, Companies and Other Business Structures in South Africa $2^{\text {nd }}$ Edition (2011) Oxford University Press Southern Africa.

Esser I, "A global perspective on African Corporate Governance: the protection of stakeholders' interests" (2007) 32 South African Yearbook of International Law: Good Governance \& Non-state Actors in International Law: an African Perspective: Regional Conference $406-429$

Esser I, "Stakeholder Protection: The Position of Employees" (2007) 70 TydskrifvirHedendaagseRomeins-HollandseReg 407.

Esser I, "The Protection of Stakeholder Interests in Terms of the South African King III Report on Corporate Governance: An Improvement on King II?" (2009) 21 SA Merc LJ 188-201.

Esser I and Dekker A, "The Dynamics in Corporate Governance in South Africa: Broad Based Black Economic Empowerment and the Enhancement of Good Corporate Principles" (2008) 3(3) J. of Int. Commercial Law and Technology 157.

Esser I and Du Plessis JJ, "The Stakeholder Debate and Directors' Fiduciary Duties" (2007) 19 SA Merc LJ 346.

Havenga M "Duties of Company Chairman" (2005) 17 SA MercLJ 137.

Havenga M, "The Company, the Constitution and the Stakeholders" (1997) 5 Juta BusinessLaw Journal 134-139.

Hendrikse JW and Hefer-Hendrikse L Corporate Governance Handbook 2nd Edition 2004 Juta\& Co. Ltd.

Ho VEH, "Enlightened Shareholder Value: Corporate Governance Beyond the Shareholder-Stakeholder Divide" 2010 36(1) The Journal of Corporation Law 59. 